\title{
C5a promotes migration, proliferation, and vessel formation in endothelial cells
}

\author{
Ryuji Kurihara $\cdot$ Kunihiro Yamaoka $\cdot$ Norifumi Sawamukai $\cdot$ \\ Shohei Shimajiri $\cdot$ Koichi Oshita $\cdot$ Sonosuke Yukawa $\cdot$ Mikiko Tokunaga $\cdot$ \\ Shigeru Iwata $\cdot$ Kazuyoshi Saito $\cdot$ Kenji Chiba $\cdot$ Yoshiya Tanaka
}

Received: 8 March 2009/Revised: 18 December 2009/ Accepted: 15 February 2010/Published online: 9 March 2010

(C) The Author(s) 2010. This article is published with open access at Springerlink.com

\begin{abstract}
Objectives The goal of this paper is to investigate the effects of activated complement C5a on vascular endothelium during vessel formation.

Methods A human microvascular endothelial cell line (HMEC-1) derived from post-capillary venules in skin was used to measure DNA synthesis, proliferation and cellcycle progression. In vitro ring-shaped formation by the cells was assessed by using type I collagen gel matrix and a cell-migration assay using the Chemotaxicell chamber. A Matrigel plug assay was performed to confirm the effect of C5a in vivo.

Results C5a progressed the cell cycle of HMEC-1 into G2/M phases, and induced DNA synthesis and proliferation in a dose-dependent manner. C5a efficiently induced migration and ring-shaped structure formation both in vitro and in vivo. Furthermore, a C5a receptor antagonist (W-54011) suppressed all HMEC-1 activities including proliferation and migration.
\end{abstract}

Responsible Editor: M. Katori.

R. Kurihara · K. Yamaoka · N. Sawamukai · K. Oshita ·

S. Yukawa $\cdot$ M. Tokunaga $\cdot$ S. Iwata $\cdot$ K. Saito

Y. Tanaka $(\square)$

The First Department of Internal Medicine,

University of Occupational and Environmental Health,

Japan, Kitakyushu 807-8555, Japan

e-mail: tanaka@med.uoeh-u.ac.jp

S. Shimajiri

Department of Pathology and Cell Biology,

University of Occupational and Environmental Health,

Japan, Kitakyushu 807-8555, Japan

K. Chiba

Pharmacology Laboratory, Research Division, Mitsubishi

Tanabe Pharma Corporation, Yokohama 227-0033, Japan
Conclusions Proliferation, migration, and ring-shaped formation by HMEC-1 cells was induced by C5a. The actions were efficiently inhibited by a specific antagonist against C5a. Our results implicated C5a in vessel formation and as a potent target for management of inflammatory diseases.

Keywords C5a - Angiogenesis - Endothelial cell · Inflammatory diseases - Activated complement

\section{Introduction}

Angiogenesis plays an important role in various inflammatory diseases. Multiple immune stimuli of both innate immunity and acquired immunity activate complement systems, often acting on mast cells via complement factors such as C3a and C5a [1]. Mast cells enhance inflammation initially by inducing the infiltration of polynuclear leukocytes to the inflamed site, subsequently to macrophages and lymphocytes [2]. Inflammation causes the endothelium to produce angiogenesis-stimulating factors, such as fibroblast growth factor 2 (FGF-2), as well as stimulating the migration and proliferation of surrounding endothelial cells. Moreover, enzymes are secreted to digest collagen in the vascular basement membrane, and proliferating endothelial cells form connections with neighbouring vessels. These angiogenic steps play a significant role in the development and chronicity of inflammatory diseases [3-8].

The complement system comprises a series of enzymes that induce inflammation in a cascade manner when activated by bacterial antigens and immune complexes. Complement activation occurs via the classical, alternate, or lectin-mediated pathways and activated complements such as C3a and C5a help to eliminate foreign substances 
by inducing inflammatory reactions, phagocytic chemotaxis, opsonisation and cytolysis [9-11].

C5a is a 74-amino-acid peptide with a molecular weight of $11.5 \mathrm{kDa}$ produced during complement activation processes [1]. C5a has multiple functions in various cells, such as mast cell degranulation, monocyte migration, smooth muscle contraction, blood vessel dilatation, recruitment of immune cells and increased vascular permeability at inflammatory sites [12]. C5a exerts its activities by binding to the G-protein-coupled $\mathrm{C} 5 \mathrm{a}$ receptor on the plasma membrane of target cells. This cellular receptor for C5a (CD88) is expressed in the liver, lung, kidney, and central nervous system $[13,14]$, with a single human neutrophil expressing 1-2 × $10^{5} \mathrm{C} 5$ a receptors [1]. C5a activity has been implicated in various diseases such as rheumatoid arthritis, systemic lupus erythematosus, reperfusion injury, Alzheimer's disease and sepsis [15-21]. Indeed, activated complement proteins including $\mathrm{C} 5 \mathrm{a}$ have been identified together with proinflammatory mediators such as cytokines and proliferating neutrophils and macrophages in synovial fluid and synovial tissues of patients with rheumatoid arthritis [22-25].

C5a is closely related to chronic inflammatory diseases and possibly to angiogenesis [26]. The involvement of C5a in arthritis was confirmed in C5/C5aR-deficient mice or by using anti-C5/C5a antibodies; in both cases, the incidence of collagen-induced arthritis was reduced [13, 27]. Although C5a receptors are widely expressed including by vascular endothelial cells [9-11], the effects of activated complement molecules remain unclear.

\section{Materials and methods}

\section{Reagents}

Recombinant human C5a was purchased from Sigma (St. Louis, MO, USA). An orally active low molecular weight C5aR-antagonist, W-54011, was synthesized by Mitsubishi Tanabe Pharma Corporation according to the method described previously [13]. W-54011 is species-selective, with effects appearing only in humans, cynomolgus monkeys and gerbils [13, 14]. Type I collagen gel (Cellmatrix Type I-A) was purchased from Nitta Zeratin Co. (Osaka, Japan) and the Chemotaxicell chamber was obtained from Kurabo (Tokyo, Japan).

\section{Cell culture and treatment conditions}

The human microvascular endothelial cell-1 (HMEC-1) derived from subcutaneous postcapillary venules (ATCC, Manassas, VA, USA) was grown in Dulbecco's modified Eagle's medium (DMEM; Wako, Tokyo) supplemented with 5\% foetal bovine serum (FBS; Sigma) and penicillinstreptomycin (Gibco BRL, Tokyo).

Flow cytometry

Hanks' balanced salt solution containing $0.1 \% \quad \mathrm{NaN}_{3}$ and $1 \%$ FBS was used as the buffer in all flow cytometry experiments. Phycoerythrin (PE)-labelled anti-CD88 monoclonal antibody (PharMingen, Tokyo) was incubated with HMEC- 1 cells for $30 \mathrm{~min}$ at $4{ }^{\circ} \mathrm{C}$. After three washes, $1 \times 10^{4}$-labelled HMEC-1 cells were analyzed by fluorescence-activated cell sorting (FACS) using the FACScanmachine (Becton-Dickinson, Mountain View, CA, USA) [25].

Measurement of proliferation, apoptosis and cell cycle

To measure cell proliferation, confluent HMEC-1 cells were detached with trypsin and ethylenediaminetetraacetic acid (EDTA) solution, suspended in DMEM with 5\% FBS, and then seeded onto 96 -well plates $\left(0.32 \mathrm{~cm}^{2} /\right.$ well; Nunc, Kamstrup, Denmark). The cells were incubated until confluence. Cell growth was arrested for $24 \mathrm{~h}$ by replacing the DMEM with $0.1 \% \mathrm{FBS}$, followed by incubation at $37^{\circ} \mathrm{C}$ for $48 \mathrm{~h}$ with $\mathrm{C} 5 \mathrm{a}$ or $\mathrm{W}-54011$. $\left[{ }^{3} \mathrm{H}\right]$-thymidine was added to a final concentration of $3.7 \times 10^{5} \mathrm{~Bq} / \mathrm{mL}$ for the last $18 \mathrm{~h}$ and the cells were harvested using a semiautomatic cell harvester (Abe Kagaku, Chiba, Japan). The amount of radioactivity incorporated into the cellular DNA was measured using a scintillation counter (Aloka LSC3500ETM, Tokyo) [5].

The cell cycle stage was assessed following propidium iodine staining (PI; Sigma). HMEC-1 cells were seeded onto six-well culture plates and incubated until confluence. Cell growth was arrested for $24 \mathrm{~h}$ as described previously, washed with cold phosphate-buffered saline (PBS), and then fixed with $70 \%$ ethanol. The fixed cells were incubated with $10 \mu \mathrm{g} / \mathrm{mL}$ of ribonuclease A (RNase A) (Roche, Japan) and $50 \mu \mathrm{g} / \mathrm{mL}$ PI for $10 \mathrm{~min}$, and then the DNA content was measured by FACScan.

Apoptotic cells were counted using the Annexin V binding assay [28].

Cell viability was also measured using the Tetra Color One cell proliferation assay (Seikagaku, Tokyo), according to the instructions provided by the manufacturer. Briefly, HMEC-1 cells were seeded in $100 \mu \mathrm{L}$ DMEM with $5 \%$ FBS onto 96-multiwell plates and incubated until confluence. Cell growth was arrested for $24 \mathrm{~h}$ as described previously. The plates were incubated at $37^{\circ} \mathrm{C}$ for $48 \mathrm{~h}$, and then a tetrazolium (WST-8) mixture was added to a final volume of $110 \mu \mathrm{L} /$ well. After $2 \mathrm{~h}$ incubation, absorbance at $450 \mathrm{~nm}$ was measured using a microplate reader. Quintuplicate cultures were used in all assays. 


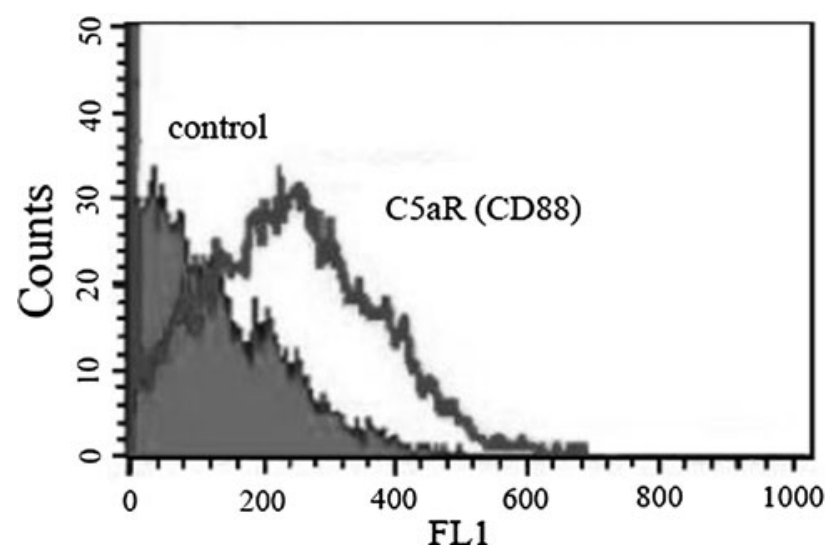

Fig. 1 Expression of C5aR (CD88) on human microvascular endothelial cells (HMEC-1). Flow cytometry results showing C5aR expression (outlined area) on HMEC-1 cells without stimulation. Dark areas indicate control

Formation of ring-shaped structures by HMEC-1

Endothelial formation of ring-shaped structures was assessed using type I collagen gel matrix. Eight volumes of $0.3 \%$ Cellmatrix type I-A solution (Nitta Gelatin) were mixed with one volume each of reconstituted buffer $(4.77 \mathrm{~g}$ HEPES and $2.2 \mathrm{~g} \mathrm{NaHCO}_{3}$ in $100 \mathrm{~mL}$ of $0.05 \mathrm{~N} \mathrm{NaOH}$ ) and Roswell Park Memorial Institute (RPMI)-1640 medium, and kept on ice. Then, $150 \mu \mathrm{L}$ aliquots were placed in each well of 12-well culture plates and immediately incubated at $37^{\circ} \mathrm{C}$ for $1 \mathrm{~h}$ to allow gel formation. After gel solidification, HMEC- 1 cells $\left(2 \times 10^{4}\right.$ cells $\left./ 0.3 \mathrm{~mL}\right)$ were added to each well and incubated at $37^{\circ} \mathrm{C}$ with $\mathrm{W}-54011$, C5a, and low-concentration FGF-2 (1 ng/mL). Finally, each well was washed with PBS. The number of cells forming ring-shaped structures was counted by inverted microscopy. Results were expressed as the mean \pm standard error of the mean (SEM) of 16 fields derived from three wells [4]. Quintuplicate cultures were used in the assay.

\section{Cell migration assay}

Cell migration activity was measured using a modified Boyden Chemotaxicell chamber (Kurabo). Polycarbonate filters with $8 \mu \mathrm{m}$ pores (Kurabo) in the inner chamber were preincubated for $1 \mathrm{~h}$ in $0.1 \%$ collagen type I (Nitta Gelatin). Cells $\left(1 \times 10^{5}\right)$ were suspended in DMEM with or without W-54011 (0.1-10 nM), and placed in the upper chambers of 24 -well plates. FGF-2 $(5 \mathrm{ng} / \mathrm{mL})$ or various concentrations of C5a $(0.1-10 \mathrm{nM})$ with $\mathrm{W}-54011$ was added to the lower chambers. The apparatus was incubated for $8 \mathrm{~h}$ at $37^{\circ} \mathrm{C}$, and then the upper chambers were disassembled. Migrated cells were defined as cells on the reverse side of the membrane and also in the lower chamber. Cells on the reverse side were removed with trypsin and counted under a microscope. Triplicate cultures were used in the assay.
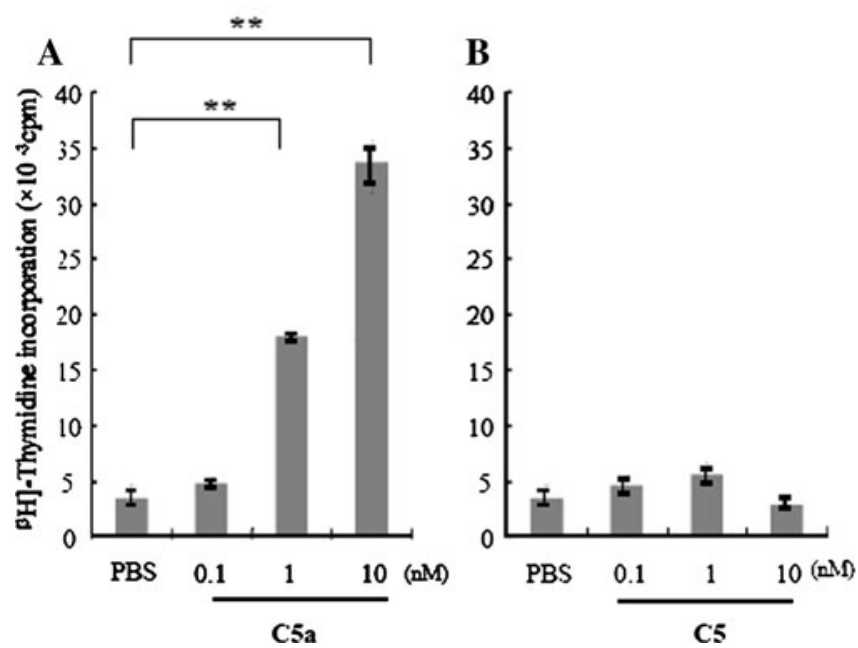

Fig. 2 Cell proliferation induced by $\mathrm{C} 5 \mathrm{a}$. $\left[{ }^{3} \mathrm{H}\right]$-thymidine incorporation was measured with a liquid scintillation counter $48 \mathrm{~h}$ after adding the various concentrations of $\mathrm{C} 5 \mathrm{a}, \mathrm{C} 5$, or $\mathrm{C} 3 \mathrm{a}$ to the HMEC-1 suspension. a C5a increased HMEC-1 proliferation in a dosedependent manner, whereas $\mathrm{C} 5$ (b) and $\mathrm{C} 3 \mathrm{a}$ (c) did not induce proliferation. d HMEC-1 was stimulated with either $10 \mathrm{nM} \mathrm{C5a}$ in the
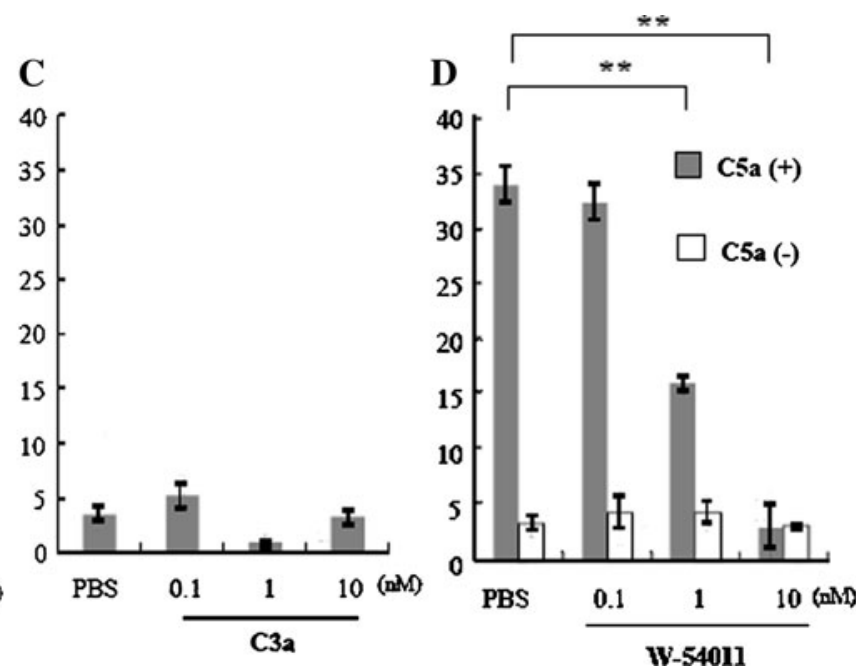

presence of various concentrations of $\mathrm{C} 5 \mathrm{a}$ receptor antagonist W-54011 (closed column) or W-54011 alone (open column). The addition of $\mathrm{W}-54011$ inhibited cell proliferation induced by $\mathrm{C} 5 \mathrm{a}$ $10 \mathrm{nM}$ in a dose-dependent manner, whereas W-54011 alone had no effect. Bars represent mean \pm SEM $(n=5)$. $* * P<0.01$ by Dunnett's multiple comparison test 
A

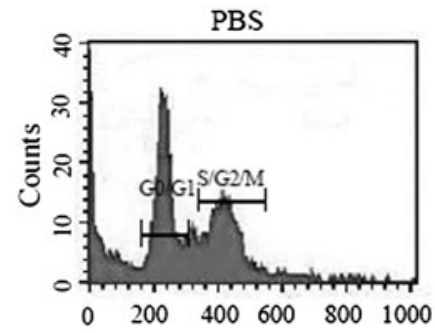

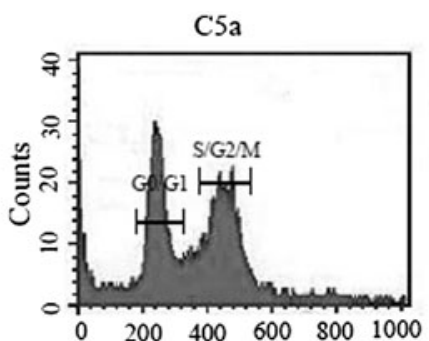

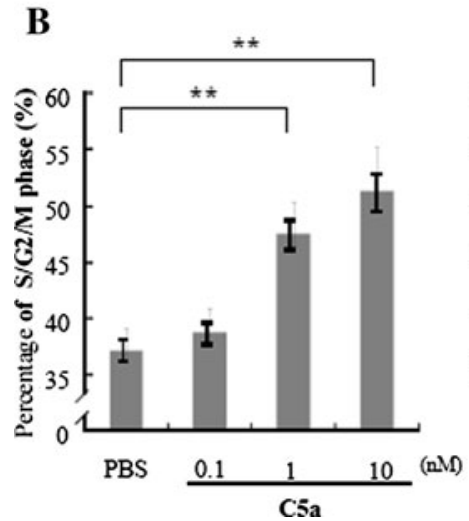

C

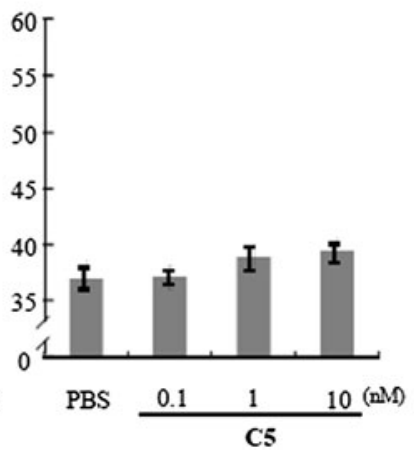

Fig. 3 Cell cycle progression induced by C5a. HMEC-1 cultures were incubated with $10 \mathrm{nM} \mathrm{C5a}$ or the indicated concentrations of $\mathrm{C5}$ and $\mathrm{C} 3 \mathrm{a}$. Cell cycle phases were determined by flow cytometry with PI staining enabling the determination of cells in the G0/G1 and S/G2/ $\mathrm{M}$ phases. a Cells in the S/G2/M phases advanced significantly when stimulated with $10 \mathrm{nM} \mathrm{C5a}$ for $48 \mathrm{~h}$, and this effect was suppressed by the addition of $10 \mathrm{nM}$ W-54011. b C5a promoted cell cycle
D
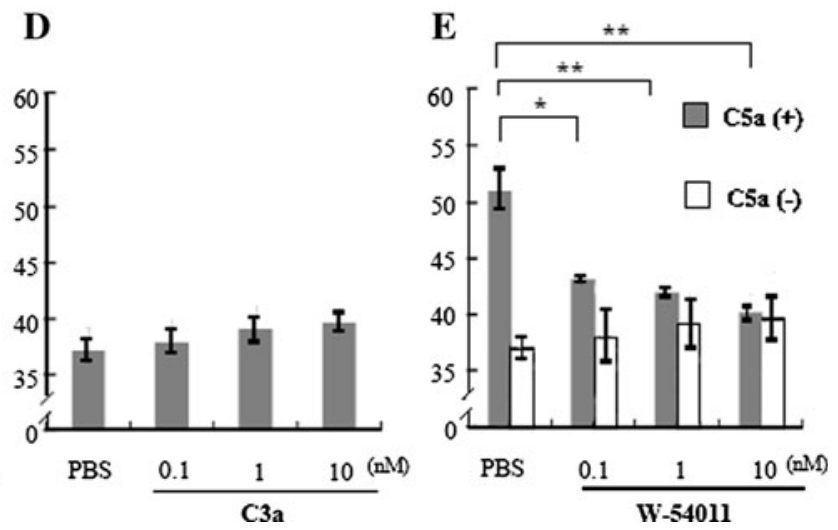

progression in a dose-dependent manner, C5 (c) and C3a (d) had no effect on the stage of cell cycle. $\mathbf{e}$ The indicated concentrations of $\mathrm{W}-54011$ were added in the presence of $10 \mathrm{nM} \mathrm{C5a}$ (closed bars) or without C5a (open bars). W-54011 suppressed the effect of C5a on cell cycle whereas W-54011 alone had no effect. Bars represent mean \pm SEM $(n=5) . * P<0.05$ and $* * P<0.01$ by Dunnett's multiple comparison test
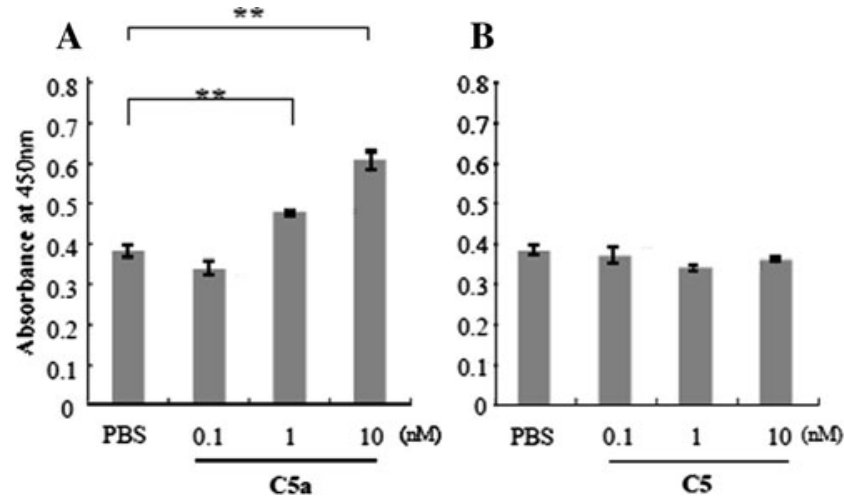

Fig. 4 Cell viability was measured using the Tetra Color One assay. The optical density of each well was measured at $450 \mathrm{~nm}$. Phosphatebuffered saline $(P B S)$ alone was added to control samples. a C5a increased the number of viable HMEC- 1 cells at 1 and $10 \mathrm{nM}$, while

Matrigel plug assay

All animal experiments were performed according to the guidelines for the care and use of animals approved by the University of Occupational and Environmental Health, Japan. Wild-type male C57BL/6 mice weighing 15-20 g were obtained from Charles River Japan. Surgical
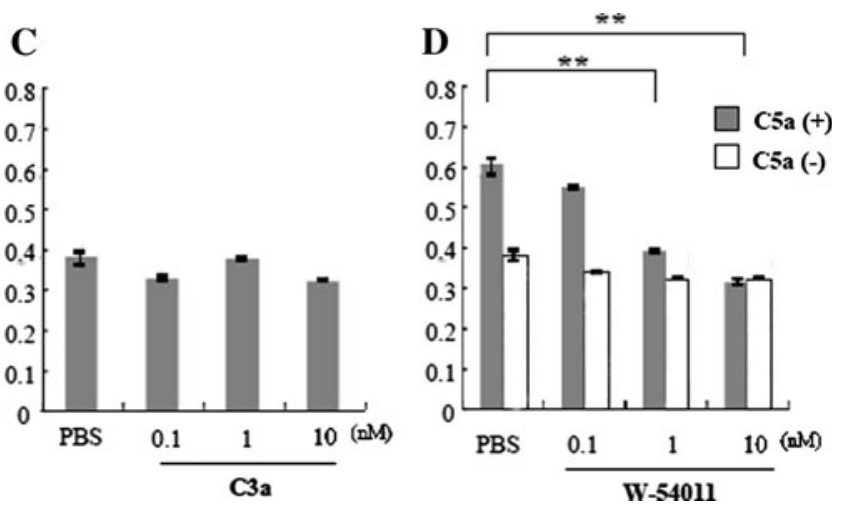

C5 (b) and C3a (c) had no such effects. d W-54011 inhibited the C5aaugmented viable cell count (closed bars), but had no effect when added alone (open bars). Bars represent mean \pm SEM $(n=5)$. $* * P<0.01$ by Dunnett's multiple comparison test

procedures were conducted under anesthesia (diethyl ether was administered by inhalation for $3 \mathrm{~min}$ ). Growth factor reduced Matrigel (BD Biosciences, Bedford, MA, USA) was prepared just before use under sterile conditions. Matrigel solidifies rapidly at $22-35^{\circ} \mathrm{C}$, and thus it was kept on ice during each experiment. Matrigel in liquid form at $4^{\circ} \mathrm{C}$ was mixed with the experimental solution $(0.05 \mathrm{~mL})$, 


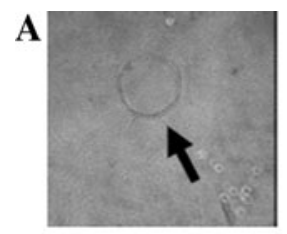

PBS

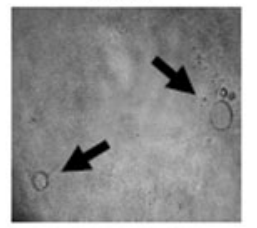

FGF-2
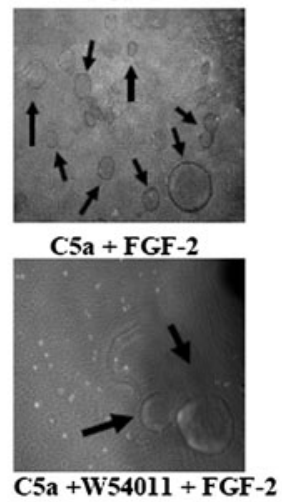

B
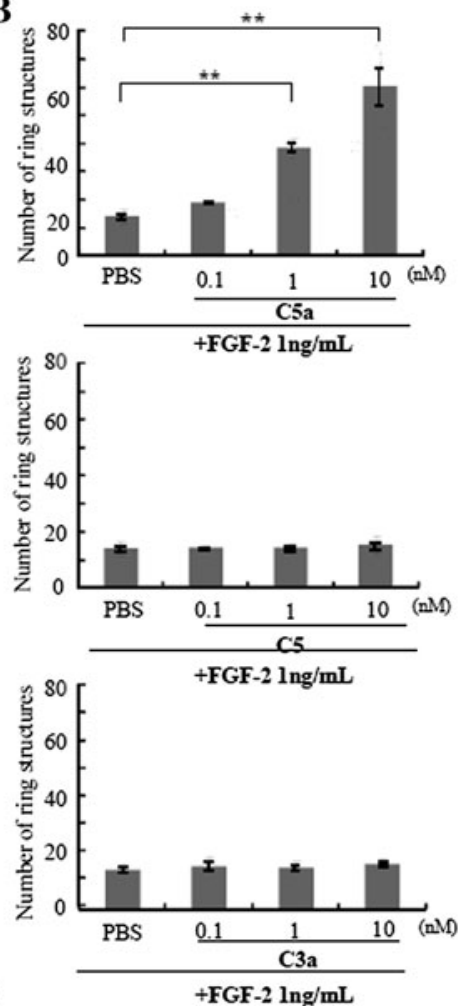

C

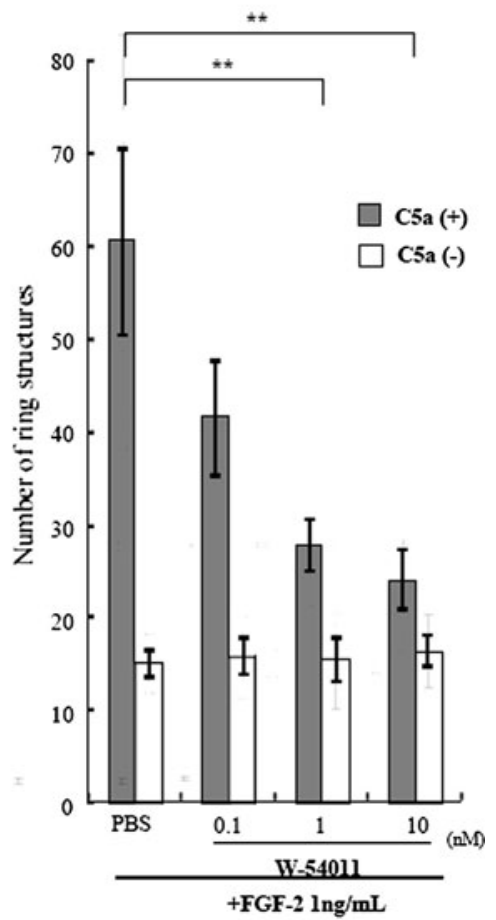

Fig. 5 Formation of ring-shaped structures in vitro. a Cells incubated in the presence of phosphate-buffered saline $(P B S)$ alone showed minimal ring-shaped arrangements of the endothelial cells. Fibroblast growth factor 2 (FGF-2; $1 \mathrm{ng} / \mathrm{mL}$ ) induced slight ring-structure formation, while $10 \mathrm{nM}$ C5a dramatically increased the number of ring-shape structures. This C5a-induced effect was inhibited by W-54011. Original magnification: $\times 40$. b C5a increased the number of ring-shaped structures formed by HMEC-1 in a dose-dependent manner compared with FGF-2 alone. C5 and C3a did not induce the formation of ring-shaped structures. $\mathbf{c}$ W-54011 inhibited ring-shaped structure formation in a dose-dependent manner (closed bars) whereas W-54011 alone had no effect (open bars). Bars represent mean $\pm \operatorname{SEM}(n=5)$. $* * P<0.01$ by Dunnett's multiple comparison test and injected $(0.5 \mathrm{~mL})$ subcutaneously in the abdominal cavity. The final concentrations used in experiments were $1 \mu \mathrm{g} / \mathrm{mL}$ for FGF-2, $1 \mu \mathrm{M}$ for C3a, and $100 \mathrm{nM}$ for C5a. All mice were injected at approximately the same sites. Mice were sacrificed 14 days after implantation to remove Matrigel plugs. The plugs were fixed and processed into the paraffin for immunohistochemical staining of sections was performed using anti-CD31 antibodies (Abcam, Cambridge, UK). Sections were counterstained with hematoxylin-eosin (H\&E). The areas containing infiltrating cells were identified by visually scanning the entire section of each tissue sample [29-31].

\section{Statistical analysis}

Values were expressed as mean \pm SEM. Differences between groups were examined by the Bonferroni's multiple comparison test. Differences between the control and the other groups were examined by Dunnett's multiple comparison test. A $P$ value $<0.05$ was considered statistically significant.

\section{Results}

C5a induces proliferation of HMEC-1 cells

First, we used flow cytometric analysis to confirm that our HMEC-1 endothelial cell line expressed the C5a receptor (CD88) as expected (Fig. 1). Once established, the cells were stimulated with different concentrations of C5a and analyzed by $\left[{ }^{3} \mathrm{H}\right]$-thymidine incorporation to assess cell proliferation. C5a induced a significant proliferation of HMEC-1 in a concentration-dependent manner, whereas other complement factors, $\mathrm{C} 5$ and $\mathrm{C} 3 \mathrm{a}$, had no such effect (Fig. 2a, b, c). The addition of W-54011, a specific C5areceptor antagonist, significantly inhibited C5a-induced proliferation in a dose-dependent manner, whereas W-54011 alone had no effect (Fig. 2d).

\section{C5a enhances cell cycle progression}

We next investigated the effect of C5a on cell cycle progression in the HMEC-1 cells. Cells were incubated with 

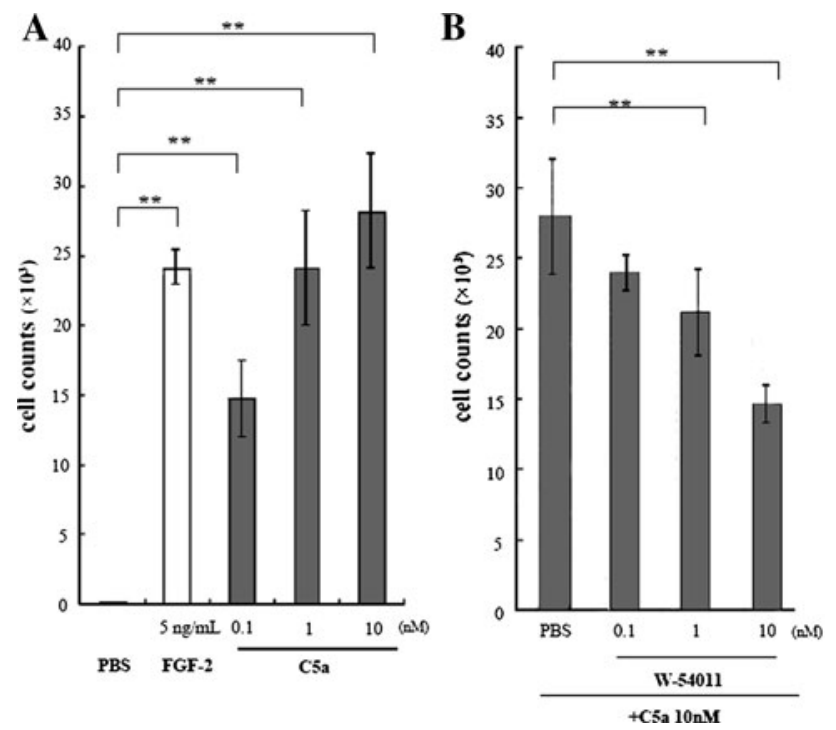

Fig. 6 Analysis of HMEC-1 migration. HMEC-1 cells migrated to the reverse side of the filters were removed with trypsin and counted. a FGF-2 $(5 \mathrm{ng} / \mathrm{ml})$ was used as a positive control for inducing HMEC-1 migration (open column). C5a increased the migration of HMEC-1 cells in a dose-dependent manner (closed column), while this induced migration was inhibited by W-54011. b In a dosedependent manner. Bars represent mean \pm SEM $(n=3)$. a $* * P<0.01$ by Bonferroni's multiple comparison test, b $* * P<0.01$ by Dunnett's multiple comparison test

RNase and fixed with 70\% ethanol, stained with PI, and then analyzed by flow cytometry (Fig. 3a). C5a significantly promoted cell cycle progression in a dose-dependent manner at $48 \mathrm{~h}$, whereas C5 and C3a had no effect (Fig. 3b, $\mathrm{c}, \mathrm{d})$. Addition of W-54011 to the C5a incubation significantly inhibited cell cycle progression, while W-54011 alone had no effect (Fig. 3e).

\section{C5a increases viable cell counts}

The effect of C5a on cell viability was then evaluated using the Tetra Color One assay with absorbance measured at $450 \mathrm{~nm}$. C5a at both 1 and $10 \mathrm{nM}$ increased significantly the HMEC-1 viable cell counts, whereas $\mathrm{C} 5$ and $\mathrm{C} 3 \mathrm{a}$ did not affect HMEC-1 viability, even at $10 \mathrm{nM}$ (Fig. 4a, b, c). The addition of 1 or $10 \mathrm{nM} \mathrm{W-54011} \mathrm{suppressed} \mathrm{the} \mathrm{pro-}$ liferative effects of $10 \mathrm{nM}$ C5a. Importantly, W-54011 alone had no effect on viable cell counts, confirming its low toxicity (Fig. 4d).

\section{C5a increases ring-shaped structures of HMEC-1 cells}

HMEC-1 cultures supplemented with $1 \mathrm{ng} / \mathrm{mL}$ FGF-2 contained a low proportion of ring-shaped structures. However, C5a at both 1 and $10 \mathrm{nM}$ markedly increased the number of ring-shaped structures per well in a dosedependent manner. Again, C5 and C3a had no similar effect (Fig. 5a, b). Furthermore, the formation of ringshaped structures induced by C5a was inhibited by W-54011 dose-dependently (Fig. 5c).

C5a enhances cell migration

FGF-2 is a known inducer of endothelial cell migration [32]. The migration by FGF-2 was confirmed in this study with the HMEC-1 line using the Chemotaxicell chamber (Fig. 6a). C5a promoted HMEC-1 migration in a dosedependent manner, an effect that was inhibited in the presence of W-54011 (Fig. 6a, b).

C5a induces infiltration and microvascular-like structure of endothelial cells in vivo

To confirm the in vitro results in an in vivo model, Matrigel plugs supplemented with PBS (controls), FGF-2, C5a, or C3a were implanted subcutaneously into mice. Significant cell infiltration into the plugs was observed in the presence of FGF-2, whereas PBS-control plugs showed minimal cell infiltration (Fig. 7a, e). As expected, C5a, but not C3a, also induced cell infiltration (Fig. 7b, f and d, h). Furthermore, both C5a and FGF-2 induced infiltration of adipocytes into the plugs, suggesting early stage angiogenesis. To confirm the endothelial cell infiltration, the Matrigel plugs were sectioned and then stained with anti-CD31 antibody. $\mathrm{CD} 31^{+}$endothelial cells were scarce in plugs supplemented with PBS and C3a. However, the addition of FGF-2 or $\mathrm{C} 5 \mathrm{a}$ induced accumulation of $\mathrm{CD} 31^{+}$endothelial cells in the plugs and subsequent formation of microvascular-like structure (Fig. 7e-h). Thus, the in vivo results mirrored those observed in vitro.

\section{Discussion}

C5a plays a role in the immune response including inflammation. Angiogenesis also occurs at inflammatory sites; however, the role of $\mathrm{C} 5 \mathrm{a}$ in angiogenesis remains unclear. In particular, its effect on the proliferation or migration of vascular endothelial cells is unknown, despite findings that C5a induces genes encoding ICAM-1 and E-selectin in vascular endothelium [33]. The present study found that C5a causes an increase in the ratio of the S/G2/M cell-cycle phases in cultured vascular endothelial cells. Furthermore, the increase in both $\left[{ }^{3} \mathrm{H}\right]$-thymidine uptake and viable cell count indicated a critical role for $\mathrm{C} 5 \mathrm{a}$ in the proliferation of these cells. Finally, these effects were all suppressed by the addition of a C5a receptor antagonist (W-54011).

C5a has a chemotactic effect on various immune cells including monocytes [34, 35], although a similar activity toward endothelial cells is unknown. In this study, C5a 

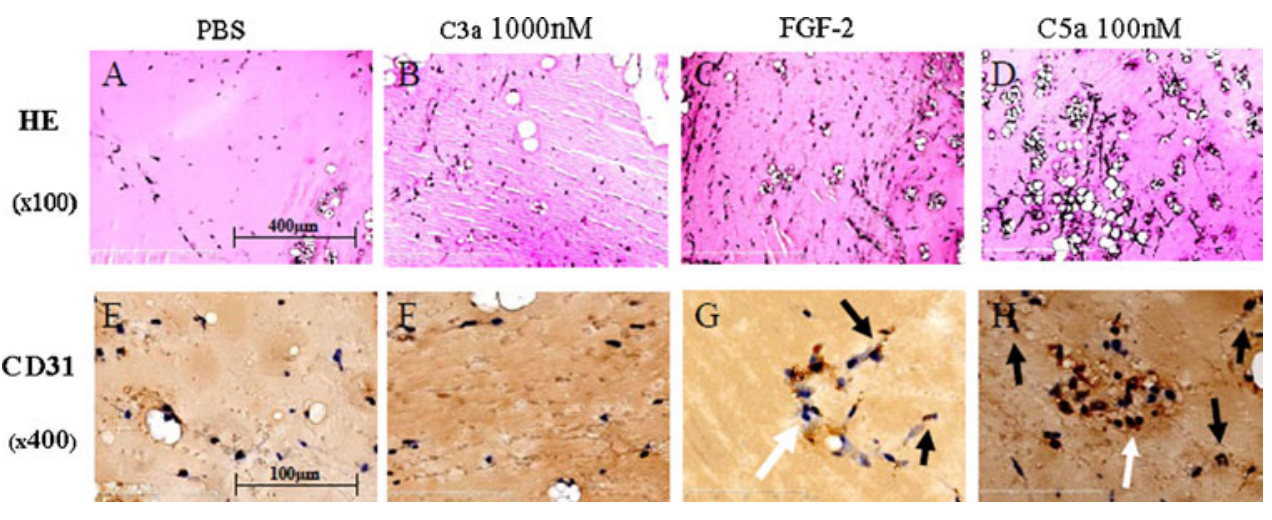

Fig. 7 Endothelial cell infiltration and microvascular-like structures induced by $\mathrm{C} 5 \mathrm{a}$ in vivo. Representative photomicrographs of Matrigel supplemented with phosphate-buffered saline $(P B S)(\mathbf{a}, \mathbf{e}), 1,000 \mathrm{nM}$ C3a $(\mathbf{b}, \mathbf{f}), 1 \mu \mathrm{g} / \mathrm{ml} \mathrm{FGF-2} \mathrm{(c,} \mathrm{g),} \mathrm{or} 100 \mathrm{nM}$ C5a (d, h) stained with $\mathrm{HE}$ or anti-CD31 antibody. Endothelial cells stained positive with anti-CD31 antibody (black arrows) and these CD31 ${ }^{+}$cells formed

induced the migration of HMEC- 1 cells in vitro using a Chemotaxicell chamber and increased $\mathrm{CD} 31^{+}$endothelial cell infiltration into abdominally sited Matrigel plugs in vivo, with the cells forming ring-shaped structures in both cases. These migration-inducing activities of $\mathrm{C} 5 \mathrm{a}$ were also inhibited by W-54011, indicating that C5a exerts chemotactic effects on vascular endothelial cells and has the potential to stimulate angiogenesis.

It is noteworthy that C5a also induced the infiltration of adipocytes into the Matrigel plugs in vivo. Applications of angiogenic growth factors in models of adipogenesis and angiogenesis have been described previously [36]. Neovascularization was induced by recruitment of adipocyte precursor cells when Matrigel was implanted subdermally, supplemented with the angiogenic factor FGF-2 [36]. In our experiments, the Matrigel plug containing C5a or FGF-2 showed increased accumulation of $\mathrm{CD} 31^{+}$endothelial cells and microvascular-like structure formation with infiltration of adipocytes. These results suggested that C5a could participate in the vascularization and accumulation of adipocytes around inflamed vessels.

C5a is associated with various diseases [3-8], but efforts to develop antagonists have not yet been successful. W54011 was recently identified as an orally active, potent, nonpeptide, and competitive C5a receptor antagonist of low molecular weight $[13,14]$. In our study, W-54011 inhibited proliferation, migration, and ring-shaped structure formation of HMEC-1 cells induced by C5a, as well as the processes of vessel formation involving endothelial cells.

The involvement of $\mathrm{C} 5 \mathrm{a}$ in disease was proven in experiments with $\mathrm{C} 5 / \mathrm{C} 5 \mathrm{aR}$-deficient mice or anti-C5/C5a antibodies. As C5aR antagonists have become available, their therapeutic potential has been verified in inflammation models $[13,14,27]$. Our present results indicate that microvascular-like structure (white arrows). Cell migration into the Matrigel was limited in the presence of PBS or C3a (a, e and $\mathbf{b}, \mathbf{f})$, whereas both FGF-2 and C5a had a significant effect on cell migration $(\mathbf{c}, \mathbf{g}$ and $\mathbf{d}, \mathbf{h})$. Black arrows indicate $\mathrm{CD} 31^{+}$endothelial cells and white arrows indicate the microvascular-like structures formed by these cells in the presence of FGF-2 and C5a

the C5aR antagonist W-54011 possesses not only antiinflammatory effects but also inhibitory effects on neovascularization, suggesting a potential application for $\mathrm{W}-54011$ as a novel therapeutic agent for the management of various inflammatory diseases such as rheumatoid arthritis [13, 14].

In conclusion, the C5a-induced stimulation of vascular endothelial cells affects angiogenesis-related processes including cell proliferation, migration, and ring-shaped structure formation. Furthermore, these effects were inhibited by the addition of W-54011, a specific C5areceptor-antagonist. Thus, C5a receptor antagonists are of potential clinical use for treatment of inflammatory diseases such as rheumatoid arthritis, asthma, psoriasis, graft rejection, and inflammatory bowel diseases.

Acknowledgments We thank Ms. T. Adachi for technical assistance. This work was supported in part by a Grant-in-Aid for Scientific Research from the Ministry of Health, Labour and Welfare of Japan, the Ministry of Education, Culture, Sports, Science and Technology of Japan and the University of Occupational and Environmental Health, Japan.

Open Access This article is distributed under the terms of the Creative Commons Attribution Noncommercial License which permits any noncommercial use, distribution, and reproduction in any medium, provided the original author(s) and source are credited.

\section{References}

1. Guo RF, Ward PA. Role of C5a in inflammatory responses. Annu Rev Immunol. 2005;23:821-52.

2. Swerlick RA, Yancey KB, Lawley TJ. Inflammatory properties of human C5a and C5a des Arg/in mast cell-depleted human skin. J Invest Dermatol. 1989;93:417-22. 
3. Foreman KE, Vaporciyan AA, Bonish BK, Jones ML, Johnson $\mathrm{KJ}$, Glovsky MM, et al. C5a-induced expression of P-selectin in endothelial cells. J Clin Invest. 1994;94:1147-55.

4. Watanabe M, Fujioka-Kaneko Y, Kobayashi H, Kiniwa M, Kuwano M, Basaki Y. Involvement of integrin-linked kinase in capillary/tube-like network formation of human vascular endothelial cells. Biol Proced Online. 2005;7:41-7.

5. Hirosumi J, Ouchi Y, Watanabe M, Kusunoki J, Nakamura T, Orimo H. Effects of growth factors on cytosolic free calcium concentration and DNA synthesis in cultured rat aortic smooth muscle cells. Tohoku J Exp Med. 1989;157:289-300.

6. Sakurai D, Tsuchiya N, Yamaguchi A, Okaji Y, Tsuno NH, Kobata T, et al. Crucial role of inhibitor of DNA binding/differentiation in the vascular endothelial growth factor-induced activation and angiogenic processes of human endothelial cells. J Immunol. 2004;173:5801-9.

7. Shepro D, Morel NM. Pericyte physiology. FASEB J. 1993;7:1031-8.

8. Oikawa T, Sasaki M, Inose M, Shimamura M, Kuboki H, Hirano $\mathrm{S}$, et al. Effects of cytogenin, a novel microbial product, on embryonic and tumor cell-induced angiogenic responses in vivo. Anticancer Res. 1997;17:1881-6.

9. Monsinjon T, Gasque P, Chan P, Ischenko A, Brady JJ, Fontaine MC. Regulation by complement C3a and C5a anaphylatoxins of cytokine production in human umbilical vein endothelial cells. FASEB J. 2003;17:1003-14.

10. Schraufstatter IU, Trieu K, Sikora L, Sriramarao P, DiScipio R. Complement $\mathrm{C} 3 \mathrm{a}$ and $\mathrm{C5}$ a induce different signal transduction cascades in endothelial cells. J Immunol. 2002;169:2102-10.

11. Laudes IJ, Chu JC, Huber-Lang M, Guo RF, Riedemann NC, Sarma JV, et al. Expression and function of C5a receptor in mouse microvascular endothelial cells. J Immunol. 2002;169: 5962-70.

12. Monk PN, Scola A-M, Madala P, Fairlie DP. Function, structure and therapeutic potential of complement $\mathrm{C} 5 \mathrm{a}$ receptors. $\mathrm{Br} \mathrm{J}$ Pharmacol. 2007;152:429-48.

13. Sumichika H, Sakata K, Sato N, Takeshita S, Ishibuchi S, Nakamura M, et al. Identification of a potent and orally active non-peptide C5a receptor antagonist. J Biol Chem. 2002;277: 49403-7.

14. Sumichika H. C5a receptor antagonists for the treatment of inflammation. Curr Opin Investig Drugs. 2004;5:505-10.

15. Farkas I, Baranyi L, Liposits ZS, Yamamoto T, Okada H. Complement C5a anaphylatoxin fragment causes apoptosis in TGW neuroblastoma cells. Neuroscience. 1998;86:903-11.

16. Riedemann NC, Guo RF, Neff TA, Laudes IJ, Keller KA, Sarma $\mathrm{VJ}$, et al. Increased C5a receptor expression in sepsis. J Clin Invest. 2002;110:101-8.

17. Barnum SR. Complement in central nervous system inflammation. Immunol Res. 2002;26:7-13.

18. Nataf S, Stahel PF, Davoust N, Barnum SR. Complement anaphylatoxin receptors on neurons: new tricks for old receptors? Trends Neurosci. 1999;22:397-402.

19. Barnum SR, Ames RS, Maycox PR, Hadingham SJ, Meakin J, Harrison D, et al. Expression of the complement C3a and C5a receptors after permanent focal ischemia: an alternative interpretation. Glia. 2002;38:169-73.

20. Riedemann NC, Guo RF, Hollmann TJ, Gao H, Neff TA, Reuben JS, et al. Regulatory role of C5a in LPS-induced IL-6 production by neutrophils during sepsis. FASEB J. 2004;18:370-2.
21. Rittirsch D, Flierl MA, Nadeau BA, Day DE, Huber-Lang M, Mackay CR, et al. Functional roles for C5a receptors in sepsis. Nat Med. 2008;14:551-7.

22. Jose PJ, Moss IK, Maini RN, Williams TJ. Measurement of the chemotactic complement fragment $\mathrm{C} 5 \mathrm{a}$ in rheumatoid synovial fluids by radioimmunoassay: role of $\mathrm{C} 5 \mathrm{a}$ in the acute inflammatory phase. Ann Rheum Dis. 1990;49:747-52.

23. Grant EP, Picarella D, Burwell T, Delaney T, Croci A, Avitahl N, et al. Essential role for the C5a receptor in regulating the effector phase of synovial infiltration and joint destruction in experimental arthritis. J Exp Med. 2002;196:1461-71.

24. Denk A, Goebeler M, Schmid S, Berberich I, Ritz O, Lindemann $\mathrm{D}$, et al. Activation of NF- $\kappa \mathrm{B}$ via the $\mathrm{I} \kappa \mathrm{B}$ kinase complex is both essential and sufficient for proinflammatory gene expression in primary endothelial cells. J Biol Chem. 2001;276:28451-8.

25. Kiener HP, Baghestanian M, Dominkus M, Walchshofer S, Ghannadan M, Willheim M, et al. Expression of the C5a receptor (CD88) on synovial mast cells in patients with rheumatoid arthritis. Arthritis Rheum. 1998;41:233-45.

26. Paleolog EM. Angiogenesis in rheumatoid arthritis. Arthritis Rev. 2002;S81-90.

27. Wang Y, Rollins SA, Madri JA, Matis LA. Anti-C5 monoclonal antibody therapy prevents collagen-induced arthritis and ameliorates established disease. Proc Natl Acad Sci USA. 1995;92:8955-9.

28. Vermes I, Haanen C, Steffens-Nakken H, Reutelingsperger C. A novel assay for apoptosis. Flow cytometric detection of phosphatidylserine expression on early apoptotic cells using fluorescein labelled Annexin V. J Immunol Methods. 1995; 184:39-51.

29. Lin X, Takahashi K, Campion SL, Liu Y, Gustavsen GG, Pena LA, et al. Synthetic peptide F2A4-K-NS mimics fibroblast growth factor-2 in vitro and is angiogenic in vivo. Int $\mathrm{J}$ Mol Med. 2006;17:833-9.

30. Stieger SM, Bloch SH, Foreman O, Wisner ER, Ferrara KW, Davton PA. Ultrasound assessment of angiogenesis in a Matrigel model in rats. Ultrasound Med Biol. 2006;32:673-81.

31. Tamarat R, Silvestre JS, Durie M, Lew BI. AngiotensinII angiogenic effect in vivo involves vascular endothelial growth factor and inflammation related pathways. Lab Invest. 2002;82:747-56.

32. Barkefors I, Le Jan S, Jakobsson L, Hejll E, Carlson G, Johansson $\mathrm{H}$, et al. Endothelial cell migration in stable gradients of vascular endothelial growth factor A and fibroblast growth factor 2: effects on chemotaxis and chemokinesis. J Biol Chem. 2008;283:1390512.

33. Albrecht EA, Chinnaiyan AM, Varambally S, Kumar-Sinha C, Barrette TR, Sarma JV, et al. C5a-induced gene expression in human umbilical vein endothelial cells. Am J Pathol. 2004;164:849-59.

34. Hartmann K, Henz BM, Krüger-Krasagakes S, Köhl J, Burger R, Guhl S, et al. C3a and C5a stimulate chemotaxis of human mast cells. Blood. 1997;89:2863-70.

35. Falk W, Leonard EJ. Human monocyte chemotaxis: migrating cells are a subpopulation with multiple chemotaxin specificities on each cell. Infect Immun. 1980;29:953-9.

36. Kawaguchi N, Toriyama K, Nicodemou-Lena E, Inou K, Torii S, Kitagawa Y. De novo adipogenesis in mice at the site of injection of basement membrane and basic fibroblast growth factor. Proc Natl Acad Sci USA. 1998;95:1062-6. 